\title{
DNA profiling of Hungarian King Béla III and other skeletal remains originating from the Royal Basilica of Székesfehérvár
}

\author{
Judit Olasz $^{1}$ (10 $\cdot$ Verena Seidenberg $^{2} \cdot$ Susanne Hummel ${ }^{2} \cdot$ Zoltán Szentirmay $^{1} \cdot$ György Szabados $^{3} \cdot$ Béla Melegh $^{4}$. \\ Miklós Kásler ${ }^{1}$
}

Received: 1 December 2017 / Accepted: 23 January 2018 / Published online: 10 February 2018

(C) The Author(s) 2018. This article is an open access publication

\begin{abstract}
A few decades after the collapse of the Avar Khaganate (c. 822 AD), Hungarian invaders conquered the Carpathian Basin (c. 862-895 AD). The first Hungarian ruling dynasty, the Árpáds played an important role in European history during the Middle Ages. King Béla III (1172-1196) was one of the most significant rulers of the dynasty. He also consolidated Hungarian dominance over the Northern Balkans. The provostry church of the Virgin Mary (commonly known as the Royal Basilica of Székesfehérvár) played a prominent role as a coronation church and burial place of medieval Hungarian kings. The basilica's building and graves had been destroyed over the centuries. The only royal graves that remained intact were those of King Béla III and his first spouse, Anna of Antioch. These graves were discovered in 1848. We defined the autosomal STR (short tandem repeat) fingerprints of the royal couple and eight additional individuals (two females and six males) found in the Royal Basilica. These results revealed no evidence of first-degree relationship between any of the investigated individuals. Y-chromosomal STR profiles were also established for all the male skeletons. Based upon the Y-chromosomal data, one male skeleton showed an obvious patrilineal relationship to King Béla III. A database search uncovered an existing Y-chromosomal haplotype, which had a single-repeat difference compared to that of King Béla. It was discovered in a person living in an area close to Hungary. This current male line is probably related paternally to the Árpád Dynasty. The control region of the mitochondrial DNA was determined in the royal couple and in the remains of the inferred relative. The mitochondrial results excluded sibling relationship between the King and the patrilineal relative. In summary, we successfully defined a Y-chromosomal profile of King Béla III, which can serve as a reference for the identification of further remains and disputed living descendants of the Árpád Dynasty. Among the examined skeletons, we discovered an Árpád member, whose exact affiliation, however, has not yet been established.
\end{abstract}

Keywords Ancient DNA $\cdot$ STR typing $\cdot$ Kinship analysis $\cdot$ mtDNA $\cdot$ Hungarian kings $\cdot$ Árpáds

Electronic supplementary material The online version of this article (https://doi.org/10.1007/s12520-018-0609-7) contains supplementary material, which is available to authorized users.

Judit Olasz

olasz@oncol.hu

1 National Institute of Oncology, Ráth Gy. u. 7-9, Budapest 1122, Hungary

2 Historical Anthropology and Human Ecology, Johann-Friederich-Blumenbach Institute of Zoology and Anthropology, University of Goettingen, Buergerstr. 50, 37073 Goettingen, Germany

3 King St. Stephen Museum, Fő u. 6, Székesfehérvár 8000, Hungary

4 Department of Medical Genetics, University of Pécs, Szigeti u. 12, Pécs 7624, Hungary

\section{Introduction}

The Árpád Dynasty (c. 850-1301 AD) played an important role in European history during the Middle Ages (Hóman 1940-1943). The first Great Prince Álmos organised the monarchic state in the northern region of the Black Sea c. 850. A few decades after the collapse of the Avar Khaganate (c. $822 \mathrm{AD})$, Álmos and his son Árpád conquered the Carpathian Basin (c. 862-895 AD) (Szöke 2014). During the conquest, Hungarian invaders, together with Turkicspeaking Kabars assimilated the Avars and Slavonic groups (Szádeczky-Kardoss 1990). Thus, most of the population in the Carpathian Basin originated from the Hun-Turkic cultural community of the Eurasian Steppe and was accompanied by Slavonic and German-speaking groups (László 1996). The origin of Hungarians is still controversial, and this paper 
cannot cover this complex subject. The Hungarian Great Principality represented the Eurasian steppe empires in Central Europe from c. 862 until 1000. Saint Stephen I, the last Great Prince (997-1000) and first King (1000-1038) of Hungary re-organised this early Hungarian state as a Christian kingdom. Saint Stephen received the royal crown from the Pope and joined the post-Roman Christian political system and cultural commonwealth of Latin Europe (Pohl 2003; Szabados 2011). Hungary remained an independent state between the German and Byzantine empires (Makk 1989). King Béla III (1172-1196) was one of the most significant rulers of the dynasty. He was the second son of King Géza II (11411162) and Queen Euphrosyne, the daughter of Mstislav I (1125-1132), the Great Prince of Kiev. Through the mediation of Byzantine Emperor Manuel I Komnenos, Béla married Anna of Châtillon from Antioch (1150-1184), the half-sister of the Emperor's wife in 1170. After Manuel's death, King Béla consolidated Hungarian dominance over the Northern Balkans.

The provostry church of the Virgin Mary (commonly known as the Royal Basilica of Székesfehérvár) was built by Saint Stephen I at the beginning of the eleventh century. The basilica played a prominent role as a church of coronation and as the main burial place of Hungarian kings in the Middle Ages. Fifteen kings, several queens, princes and princesses and clerical and secular dignitaries were buried there over five centuries (Engel 1987).

According to sources, ten Árpáds-eight kings and two princes-were laid to rest in the basilica (Table 1) (Szentpétery 1937-1938). Other princes who died at an early age may also be entombed there.

The Turks occupied the city of Székesfehérvár in 1543. The Turks, and later the Christian mercenaries, plundered and destroyed the graves of the basilica. The building exploded and burned down in 1601. Following the liberation from Turkish rule in 1688, the remaining stones of the basilica were carried away for reconstruction of the town. Hardly any traces of the basilica remained by the beginning of the nineteenth century. The only royal graves that remained intact were those of King Béla III and his first spouse, Anna of Antioch (1150-1184). These graves were lined with red marble slabs and were discovered during sewer construction in 1848. The royal couple were reliably identified based on their regalia and anthropological features (Érdy 1853). The following facts support the identity of the royal remains: (1) The anthropologically estimated ages of the skeletons were similar to the historically recorded ages (Érdy 1853; Éry 2008). (2) The archaeological studies dated the grave goods (the crowns, rings, sword and cross) to the twelfth century (Kovács 1969). (3) The sarcophagi had no engraved inscriptions. These were made only from the thirteenth century onward. (4) The stature of the male skeleton was remarkably tall. When the Third Crusade crossed Hungary in 1189, Richard Canonicus of London met King Béla III and noted his exceptional tallness. (5) The Nordic features of the male skeleton probably came from the King's Rurik ancestors. Béla's mother, Euphrosyne, and his paternal great-grandmother, Predslava, were both Rurikids with Viking origins. (6) The facial reconstruction of the man's skull looks a lot like the herm of King Ladislas I. Since Ladislas I was canonised during the reign of King Béla III, the latter is supposed to have been the model for the herm (László 1965). (7) The female's skeleton bears the signs of several pregnancies. This observation is in line with the fact that Queen Anna of Antioch gave birth to seven children. All these aspects apply only to the royal couple of Béla and Anna (Szabados 2016).

Following the discovery in 1848, further archaeological excavations were conducted intermittently for more than 150 years $(1848,1862,1874,1882,1936-1937,1965-$ 2002) (Éry 2008), but no other medieval kings could be identified with certainty.

The molecular genetic methods available today enable genetic examination of ancient bones. For example, they have enabled identification of the remains of King Richard III (King et al. 2014). Such studies, however, have not yet been conducted on the human remains of the basilica. We investigated skeletal remains excavated by János Érdy (1848) (Érdy 1853) and Imre Henszlmann (1862 and 1874) and later reinterred in the Matthias Church of Buda (1862 and 1900) (Table 2, online resource 1). The remains were re-examined first by Aurél Török in 1863 and 1893 (Török 1893, 1900) and last by Kinga Éry et al. in 1984 (Éry 2008). Éry et al. doubted the authenticity of a male skeleton believed to be found near Béla III (online resource 1) because of the following observations: First, Török and Éry estimated the person's age to be approximately 20-22 years (Török 1900) and 20-26 years, ${ }^{1}$ respectively, at the time of death. These estimates were in contrast to the initial estimation of more than 30 years of age (Érdy 1853). Second, they discerned that the missing bones of this skeleton were different from those marked on an original drawing made in 1848 (e.g., the skull disappeared). Third, they also noted that the colour of this skeleton was yellowish, even though it was muddied at the time of discovery (Érdy 1853; Éry 2008). Due to these observations, they excluded this skeleton from further study. This skeleton is noted as $\mathrm{II} / 52$ in our study.

\footnotetext{
${ }^{1}$ Data obtained from the documentation of human remains of the Székesfehérvár Royal Basilica, Anthropological Repository of Saint Stephen Museum, Székesfehérvár.
} 
Table 1 The Árpád Dynasty members who were buried in Székesfehérvár

\begin{tabular}{lllll}
\hline Name & Birth & Death & Reign & Genealogical Affiliation \\
\hline Prince Saint Emeric & $1000 / 07$ & 1031 & - & King Saint Stephen's son \\
King Saint Stephen I & c. 980 & 1038 & $997-1038$ & $5^{\text {th }}$ descendant of Great Prince Álmos \\
King Coloman the Learned & c. 1070 & 1116 & $1095-1116$ & Great-grandson of Prince Vazul, King Saint Stephen's cousin \\
Prince Álmos & c. 1071 & 1127 & - & King Coloman's younger brother \\
King Béla II the Blind & c. 1108 & 1141 & $1131-1141$ & Son of Prince Álmos \\
King Géza II & 1130 & 1162 & $1141-1162$ & Son of King Béla II \\
King Ladislas II & c. 1131 & 1163 & $1162-1163$ & Younger brother of King Géza II \\
King Stephen IV & c. 1133 & 1165 & 1163 & Younger brother of King Ladislas II \\
King Béla III the Great & c. 1148 & 1196 & $1172-1196$ & Son of King Géza II \\
King Ladislas III & c. 1200 & 1205 & $1204-1205$ & Grandson of King Béla III \\
\hline
\end{tabular}

The establishment of a dignified resting place and creation of a shrine for the House of Árpád kings were parts of the objectives set forth by the House of Árpád Programme (1832/2013). The National Institute of Oncology undertook genetic profiling of the human remains from the Royal Basilica to identify skeletal remains possibly belonging to the Royal Dynasty. The objectives of our study were to define the Y-chromosomal STR (short tandem repeat) profile of King Béla III and to determine the autosomal STR-based DNA fingerprints of the royal couple. Furthermore, our aim was to perform genetic profiling on some of the other skeletons from the Basilica to identify royal relatives. We intended to establish a molecular base for the identification of possible future finds of the Árpád Dynasty and for reconstruction of their genealogy. Therefore, our research team opened the metal caskets of Matthias Church in March 2014.

\section{Materials and methods}

\section{Samples}

The opening of the sarcophagi, compilation of the skeletons and sampling were carried out with the participation of archaeologists and anthropologists. The procedures were recorded in a written report with photodocumentation. The sealed metal caskets and, in the case of the royal couple, additional inner glass boxes, were opened by a restorer. The innermost wooden cases, which contained the skeletal remains, were placed in new, clean plastic boxes for transportation. The person carrying out this procedure wore a scrub suit, disposable gloves and a facial mask. The skeletons were compiled in a sterile operating room of the National Institute of Oncology. The operating table was

Table 2 The examined skeletal remains

\begin{tabular}{|c|c|c|c|c|c|}
\hline Skeleton & Sex & Estimated age & Position in the Royal Basilica & Grave & Archaeological dating \\
\hline Béla III (I) & Male & $45-49^{\mathrm{a}}$ & South nave $e^{\mathrm{e}}$ & Stone & $12^{\text {th }}$ century $^{\mathrm{h}}$ \\
\hline Anna of Antioch (II) & Female & $37-41^{\mathrm{a}}$ & South nave $e^{e}$ & Stone & $12^{\text {th }}$ century $^{\text {h }}$ \\
\hline \multirow[t]{2}{*}{$\mathrm{II} / 52(=\mathrm{III} ?)$} & Male & $\begin{array}{l}\geq 30^{\mathrm{b}} \\
20-22^{\mathrm{c}}\end{array}$ & South nave ${ }^{\mathrm{e}}$ & Stone & Not available \\
\hline & & $20-26^{\mathrm{d}}$ & & & \\
\hline Foetus (IV) & & & South nave $e^{e}$ & Ground & Not available \\
\hline $\mathrm{I} / 3 \mathrm{G}$ & Male & $37-40^{\mathrm{a}}$ & North nave ${ }^{f}$ & Stone & $12^{\text {th }}$ century ${ }^{\mathrm{i}}$ \\
\hline $\mathrm{I} / 4 \mathrm{H}$ & Male & $37-41^{\mathrm{a}}$ & North nave ${ }^{f}$ & Stone & $12^{\text {th }}$ century ${ }^{\mathrm{i}}$ \\
\hline $\mathrm{II} / 53$ & Male & $21-27^{\mathrm{a}}$ & Inner church, unknown ${ }^{\mathrm{g}}$ & Ground & Not available \\
\hline $\mathrm{II} / 54$ & Male & $32-38^{\mathrm{a}}$ & Inner church, unknown ${ }^{\mathrm{g}}$ & Ground & Not available \\
\hline $\mathrm{II} / 55$ & Male & $37-42^{\mathrm{a}}$ & Inner church, unknown ${ }^{\mathrm{g}}$ & Ground & Not available \\
\hline II/109 & Female & $35-41^{\mathrm{a}}$ & Inner church, unknown ${ }^{\mathrm{g}}$ & Ground & Not available \\
\hline
\end{tabular}

${ }^{\mathrm{a}}$ Éry 2008; ${ }^{\mathrm{b}}$ Érdy $1853 ;{ }^{\mathrm{c}}$ Török $1900 ;{ }^{\mathrm{d}}$ Documentation of human remains of the Székesfehérvár Royal Basilica, Anthropological Repository of Saint Stephen Museum, Székesfehérvár; ${ }^{\mathrm{e}}$ From excavation by Érdy (1848); ${ }^{\mathrm{f}}$ From excavation by Henszlmann $(1874) ;{ }^{\mathrm{g}}$ From excavations by Henszlmann (1862 and 1873); ${ }^{h}$ Kovács (1969); ${ }^{\mathrm{i}}$ Henszlmann (1876); Kralovánszky (1989) 
prepared with a disposable surgical bed sheet for each skeleton. The sampling was carried out with sterile, surgical tools. The staff wore scrub suits, disposable gloves and facial masks. The bone samples were put in sterile, DNase- and RNase-free 50-ml centrifuge tubes. The participating persons were STR genotyped. Of note is that a number of people had come into direct contact with the skeletons since their discovery in the nineteenth century. During the excavations, transport and investigations, the bones had become contaminated. The remains, especially those of the royal couple, had been investigated several times $(1848,1883,1967$ and 1984) without precautions against DNA contamination. The details of the examined skeletons are summarised in Table 2. The bone samples used for DNA extraction are indicated in online resource 2 . The skull and poorly preserved skeletal bones of the King and Queen were consolidated using polyvinyl acetal (Alvar, Shawinigan Chemicals) in 1967. This consolidant proved to be a PCR (polymerase chain reaction) inhibitor in the first DNA extracts of the Göttingen laboratory (see the "DNA extraction" section and online resource 3).

\section{Laboratory conditions}

Y-chromosomal STR and autosomal STR analyses of the samples have been performed in parallel and independently in the Department of Pathogenetics of the National Institute of Oncology (Budapest, Hungary) and in the Department of Historical Anthropology and Human Ecology of the JohannFriedrich-Blumenbach Institute for Zoology and Anthropology (Göttingen, Germany). Overlapping STR marker panels were used to confirm the results and the reliability of both laboratories.

Budapest Sample storage, DNA isolation and PCR setup occurred in a dedicated clean-room facility supplied with a HEPA-filter and overpressure. PCR products have never been present in this area. The laboratory personnel wore disposable hooded overalls, facemasks and boot covers. Prior to experimental procedures, the working surface was decontaminated with $10 \%$ bleach, washed with Type 1 ultrapure water (Millipore), then UV-irradiated for $20 \mathrm{~min}$. Negative controls were included for every extraction procedure and PCR. The genetic profiles of the laboratory staff were also determined.

Göttingen The samples were handled in a laboratory that was twice yearly tested and certified by GEDNAP (German DNA Profiling Group). The laboratory routine (Hummel 2003) includes the following main points. The laboratories are separated strictly into a pre- and a post-PCR area, and all samples and laboratory staff pass only in the direction from pre- to
post-PCR. The pre-PCR area is entered only by fully genetically typed personnel wearing laboratory coats, hairnets and facemasks. The typing results from the ancient samples were compared to the respective data from the laboratory personnel. All working surfaces and all non-disposables are cleaned with soap (Alconox), bi-distilled water and $70 \%$ ethanol before and after the treatment of each sample. Negative controls were included in each PCR batch.

\section{DNA extraction}

The bone samples used by the laboratories for DNA extraction are summarised in online resource 2 .

Budapest The surface of the bone samples was wiped with cotton swabs soaked in $0.5 \% \mathrm{NaOCl}$ (Sigma-Aldrich). The specimens were then dipped in $0.5 \% \mathrm{NaOCl}$ solution for $15 \mathrm{~min}$ and washed three times with Type 1 ultrapure water (Millipore). The bone pieces were dried overnight and UV irradiated on every side for $10 \mathrm{~min}$. We ground the samples with Freezer/Mill (Spex Sampleprep) for 30-60 s. Decalcification of $0.15-0.20 \mathrm{~g}$ bone powder was performed in $5 \mathrm{ml}$ of $0.5 \mathrm{M}$ EDTA (pH 8.0) (Sigma-Aldrich) on roller mixer at $4{ }^{\circ} \mathrm{C}$ for $72 \mathrm{~h}$. The EDTA solution was changed every $24 \mathrm{~h}$, following centrifugation at $2500 \mathrm{~g}$ for $15 \mathrm{~min}$. The demineralised pellet was washed in $5 \mathrm{ml}$ of ultrapure water. The DNA was isolated from the pellet using DNA IQ system kit (Promega). We followed the "bone protocol" (Promega) modified with a 3-h-long digestion step. The DNA was eluted in a first $40-\mu \mathrm{l}$ fraction and a second $20-\mu \mathrm{l}$ fraction. New DNA extracts for mitochondrial sequencing analysis were also prepared. An additional $10 \mathrm{~min} 0.8 \% \mathrm{NaOCl}$ treatment of the II/ 52 femur powder and $7 \mathrm{~min} 0.5 \% \mathrm{NaOCl}$ treatments of the tarsal powders of Béla III and II/52 were applied. The bone powders were washed three times with Type 1 ultrapure water (Millipore) and processed as described above.

Göttingen Initially, the DNA of all ten samples was extracted by two different extraction methods: "QiaVac MinElute Standard" and "EZ1" (online resource 3). Because some samples, in particular those of King Béla III and Queen Anna, contained too many inhibiting substances to enable successful amplification, two new extraction methods: "QiaVac MinElute Short" (online resource 3) and "QiaVac MinElute Organic" were developed. The latter was most successful for most samples and is described below. The surface of each bone fragment was decontaminated by incubation for 15 min in commercially available bleach $(6 \% \mathrm{NaOCl})$ followed by a 15 -min rinse in bi-distilled water. The samples were dried overnight at $37^{\circ} \mathrm{C}$, then crushed in a steel mortar and powdered in a ball mill (Retsch). Approximately $0.25 \mathrm{~g}$ of bone powder was incubated with rotation with $3900 \mu \mathrm{l}$ of EDTA $(0.5 \mathrm{M} ; \mathrm{pH} 8.0)$ and $100 \mu \mathrm{l}$ of Proteinase $\mathrm{K}$ 
(600 mAnson-U/ml) at $37{ }^{\circ} \mathrm{C}$ for $18 \mathrm{~h}$. Following the $18-\mathrm{h}$ incubation, an additional $50 \mu$ l of Proteinase K (600 mAnson$\mathrm{U} / \mathrm{ml}$ ) was added, and the samples were rotated for $1 \mathrm{~h}$ at $56{ }^{\circ} \mathrm{C}$. The lysate was centrifuged for $3 \mathrm{~min}$ at 3300 . The supernatant was mixed with $3 \mathrm{ml}$ of phenol by inverting for $6 \mathrm{~min}$. For phase separation, the samples were placed for $10 \mathrm{~min}$ at $56^{\circ} \mathrm{C}$. The organic phase was removed, and the samples were mixed with $4.5 \mathrm{ml}$ of chloroform by inverting for $6 \mathrm{~min}$. The phases were separated as described above. The aqueous phase was mixed with $16 \mathrm{ml}$ of PB buffer (Qiagen) and $100 \mu$ l of sodium acetate buffer ( $3 \mathrm{M}$; pH 5.2), centrifuged for $3 \mathrm{~min}$ at $3300 \mathrm{~g}$ and transferred to MinElute columns with large-volume funnels on a QIAvac 24 Plus vacuum system (both Qiagen). The lysate was pulled through by vacuum, followed by three washing steps with $700 \mu$ l of PE buffer (Qiagen). The MinElute columns were centrifuged for $1 \mathrm{~min}$ at $15,700 \mathrm{~g}$ and then dried at room temperature with open lids for $20 \mathrm{~min}$. DNA elution was performed three times with $20 \mu \mathrm{l}$ of warm RNase-free water (Qiagen).

\section{Y-chromosomal and autosomal STR analyses}

Budapest All the STR amplifications were performed in a GeneAmp 9700 thermal cycler (Applied Biosystems). We applied $7 \mu \mathrm{l}$ of DNA from the first elutes in the commercially available STR kits. PCRs were composed and run according to the kit protocols with 34 cycles.

AmpFISTR Yfiler kit (Applied Biosystems) was used to analyse the Y-chromosomal STRs.

We used AmpFlSTR MiniFiler (Applied Biosystems), Investigator Hexaplex ESS and Investigator ESSplex Plus (both Qiagen) kits as well as self-designed tetraplex PCR to amplify autosomal STRs. Our self-designed tetraplex PCR included the markers D2S441, vWA, D10S1248 and TH01 (online resource 4). These PCR mixes contained $5 \mu \mathrm{l}$ of DNA extract, $1 \times$ GoTaq Flexi Buffer (Promega), $2 \mathrm{mM}$ $\mathrm{MgCl}_{2}, 0.2 \mathrm{mM}$ dNTPs, $3.2 \mu \mathrm{g}$ of BSA, $2.5 \mathrm{U}$ GoTaq Hot Start Polymerase (Promega) and the PCR primers (online resource 4) in a final volume of $20 \mu \mathrm{l}$. The cycling conditions were 1 cycle of $2 \mathrm{~min}$ at $95^{\circ} \mathrm{C}, 45$ cycles of $30 \mathrm{~s}$ at $94^{\circ} \mathrm{C}$, $1 \mathrm{~min}$ at $58^{\circ} \mathrm{C}, 1 \mathrm{~min}$ at $72{ }^{\circ} \mathrm{C}$ and a final extension of $50 \mathrm{~min}$ at $60{ }^{\circ} \mathrm{C}$. Simplex reactions targeting D2S441 and D3S1358 (online resource 4) (Urquhart et al. 1995; Krenke et al. 2002) were also run under the above conditions.

The PCR fragments were separated on a 3130 Genetic Analyzer (Applied Biosystems) using POP7 in a 36-cm capillary array. We evaluated the results using the GeneMapper Software v.4.0 (Applied Biosystems).

Göttingen The amplification of Y-chromosomal STRs was carried out using the Powerplex Y kit (Promega) and a labinternal decaplex Y-miniSTR-kit (for primer sequences see online resource 4$)$. The decaplex reaction setup contained $1 \times$
Qiagen Multiplex PCR Master Mix plus, $0.25 \mu \mathrm{l}$ of ammonium sulphate $(3 \mathrm{M})$ and $2.25 \mu \mathrm{l}$ of primer set. The reactions were performed using 3-4 $\mu$ l of DNA extract in a final volume of $25 \mu \mathrm{l}$. The cycling was performed in a Mastercycle (Eppendorf) and consisted of $5 \mathrm{~min}$ at $95{ }^{\circ} \mathrm{C} ; 10$ cycles of $1 \mathrm{~min}$ at $94^{\circ} \mathrm{C}, 1.5 \mathrm{~min}$ at $62^{\circ} \mathrm{C}$ and $1 \mathrm{~min}$ at $70{ }^{\circ} \mathrm{C} ; 30$ cycles of $1 \mathrm{~min}$ at $90{ }^{\circ} \mathrm{C}, 1.5 \mathrm{~min}$ at $59^{\circ} \mathrm{C}$ and $1 \mathrm{~min}$ at $70^{\circ} \mathrm{C}$. At the end of the cycling, a final elongation of $45 \mathrm{~min}$ at $60{ }^{\circ} \mathrm{C}$ was added.

Amplifications with the Powerplex Y kit (Promega) were performed with 1-3 $\mu$ l of DNA extract. The cycling consisted of $11 \mathrm{~min}$ at $94{ }^{\circ} \mathrm{C}, 1 \mathrm{~min}$ at $96^{\circ} \mathrm{C}, 10$ cycles of $1 \mathrm{~min}$ at $94{ }^{\circ} \mathrm{C}, 1 \mathrm{~min}$ at $60{ }^{\circ} \mathrm{C}, 1.5 \mathrm{~min}$ at $70{ }^{\circ} \mathrm{C}$ and 30 cycles of $1 \mathrm{~min}$ at $90^{\circ} \mathrm{C}, 1 \mathrm{~min}$ at $58^{\circ} \mathrm{C}$ and $1.5 \mathrm{~min}$ at $70{ }^{\circ} \mathrm{C}$. At the end of the cycling, a final elongation of $30 \mathrm{~min}$ at $60^{\circ} \mathrm{C}$ was added.

Self-designed heptaplex and decaplex miniSTR assays and the commercially available Investigator ESSplex SE plus and Investigator ESSplex SE QS kits (both Qiagen) were used for amplification of the autosomal STRs. The self-designed heptaplex miniSTR assay was used as described in Seidenberg et al. (2012), except that amelogenin was labelled with 6-FAM. The amplifications were performed for 40 or 45 cycles in a Mastercycler (Eppendorf) using 0.1-5 $\mu$ l of ancient DNA extracts. The decaplex miniSTR assay was used as described by Fehren-Schmitz et al. (2015) with 40 cycles using $0.5-5 \mu \mathrm{l}$ of ancient DNA extracts. Further amplifications were performed using the Investigator ESSplex SE plus and the Investigator ESSplex SE QS (both Qiagen). The PCR reactions used $0.1-5 \mu$ l of DNA extracts and ran for 40 cycles in a Mastercycler (Eppendorf).

The PCR products were checked for quality and quantity on a $2.5 \%$ agarose gel. Afterwards, the products were separated on a 3500 Genetic Analyzer (Applied Biosystems) using POP7 in 50-cm capillaries. The 3500 series Data Collection Software v2.0 was used for data collection, and the GeneMapper Software v.5.0 was used for allele determination.

Consensus profiles were generated for the samples at each laboratory. We considered an allele valid if it was present in at least two independent replicates. In the case of incomplete profiles, the results of the two laboratories were pooled before establishing a consensus profile.

Y haplogroups were statistically predicted by Athey's haplogroup predictor (http://www.hprg.com/hapest5/) (Athey 2005).

\section{Kinship analysis}

We used the "Familias 3" software (http://familias.no) (Kling et al. 2014) to perform kinship analysis based on the autosomal STR data of the persons and the population allele frequencies (Molnár et al. 2011; Rak et al. 2010). 


\section{Database search}

Y-profiles were searched against the Y Chromosome Haplotype Reference Database (YHRD) (http://yhrd.org) (Willuweit and Roewer 2015) and US Y-STR Database (https://www.usystrdatabase.org) (Fatolitis and Ballantyne 2008).

\section{Mitochondrial DNA analysis}

Budapest The complete mitochondrial control region (the hypervariable region) was determined in the samples of Béla III (tarsal), Anna of Antioch (rib) and II/52 (tarsal, femur). The control region was covered by ten overlapping PCRs using primers described by Eichmann and Parson (2008). We used the second elutes of DNA extracts as PCR templates. New DNA extracts were also prepared following an additional $\mathrm{NaOCl}$ treatment to eliminate residual mitochondrial DNA contamination (see the "DNA extraction-Budapest" section). The PCR mixes contained 2-4 $\mu$ l of DNA extract, $1 \times$ Phire Reaction Buffer (Thermo Scientific), $0.2 \mathrm{mM}$ dNTPs, $0.4 \mu \mathrm{l}$ of Phire Hot Start II DNA Polymerase (Thermo Scientific) and $0.2 \mu \mathrm{M}$ of each primer in a final volume of $20 \mu \mathrm{l}$. The cycling conditions are given in online resource 5 . The PCR products were purified with ExoSAP-IT (Affymetrix) and sequenced using BigDye Terminator v3.1 cycle sequencing kit (Applied Biosystems). The reaction products were purified with BigDye XTerminator Purification Kit and resolved on ABI PRISM 3130 Genetic Analyzer (Applied Biosystems). Data analysis was performed by the Sequencing Analysis v5.2 software. The SNPs were identified by comparison to the revised Cambridge Reference Sequence (rCRS). Sequences were confirmed by at least two different amplification products. We used the EMPOP database (http://empop.online) (Parson and Dür 2007) and HaploGrep2 (https://haplogrep.uibk.ac.at/) (KlossBrandstätter et al. 2011) to infer the mitochondrial haplogroups.

\section{Results}

\section{DNA extraction}

DNA was extracted successfully from all investigated persons. During DNA extraction from the samples of person II/52, the Budapest laboratory experienced a striking dark brown discolouration of the decalcification buffer (online resource 6). Parts of this skeleton (rib and femur), perhaps because of flooding of the grave (see the "Introduction" and "Discussion" sections), had less preserved DNA. The DNA samples of Queen Anna's rib revealed slightly lower quality DNA, which was possibly because of the thin cortical layer. Unfortunately, former contamination of the bone samples could not be controlled (see the "Samples" section). We experienced better preservation of DNA in samples from the ground graves, although the exact ages of these graves are not known.

\section{Y-chromosomal and autosomal STR analyses}

Most of the Y-chromosomal and autosomal STR results revealed very good and full profiles due to the clearly outstanding DNA preservation of most skeletal remains.

Y-STR analysis revealed a perfect match between Béla III and II/52 (Table 3, Fig. 1). All other male persons showed no patrilineal kinship with the King or with each other. The Ychromosomal STR results for each run are enclosed in online resource 7 . The most likely haplogroups according to Athey (http://www.hprg.com/hapest5/, accessed 09/03/2015) are presented in Table 3.

The consensus results for autosomal STRs are shown in Table 4 and online resource 8 . The detailed results for each run are also enclosed in online resource 8. Since the DNA samples of Anna of Antioch were of slightly poorer quality, we determined an incomplete consensus profile from the pooled data of the rib samples of both laboratories (Table 4). A partial STR profile could also be defined for the foetus (online resource 8 ) because only limited bone material was available. The autosomal STR results obtained from the femur of II/52 were inconsistent and not reproducible. Tarsal and rib samples of this person, however, yielded consistent autosomal and Y-chromosomal STR data. Following an additional 10 min $0.8 \% \mathrm{NaOCl}$ treatment of the femur powder, some of the mitochondrial PCRs ran efficiently and the sequences of the amplified fragments were identical with those of the tarsal samples (online resource 10). Presumably, the femur of II/52 was grossly contaminated. The autosomal markers were not amplifiable after the additional $\mathrm{NaOCl}$ treatment. The Y-chromosomal and autosomal STR results of II/53 obtained from the sternum and rib samples in the Göttingen laboratory showed mixed haplotypes and genotypes of at least two individuals (online resources 7 and 8). Since no male individual was involved in the processing of the samples in this lab, the results can be attributed to past human contamination. In the Budapest laboratory, we were able to extract DNA of appropriate quality from the rib and vertebra samples of this skeleton to establish a full Y-chromosomal and an almost complete autosomal STR profile (Table 3 and online resource 8 ). The morphological and molecular sex matched in all cases. 
Table 3 Y-STR consensus haplotypes of the male skeletons

\begin{tabular}{|c|c|c|c|c|c|c|c|}
\hline & Béla III & II/52 & I/3G & $\mathbf{I} / \mathbf{4 H}$ & II $/ 53$ & II/54 & II $/ 55$ \\
\hline \multicolumn{8}{|l|}{ STR loci } \\
\hline DYS19 & 16 & 16 & 15 & 14 & 13 & 16 & 14 \\
\hline DYS385 a, b & 11,13 & 11,13 & 12,17 & 11,16 & 15,19 & 11,14 & 11,14 \\
\hline DYS389 I & 13 & 13 & 14 & 13 & 13 & 13 & 13 \\
\hline DYS389 II & 33 & (33) & 30 & 29 & 30 & 30 & 29 \\
\hline DYS390 & 25 & 25 & 23 & 24 & 23 & 25 & 25 \\
\hline DYS391 & 11 & 11 & 10 & 10 & 10 & 10 & 10 \\
\hline DYS392 & 11 & 11 & 13 & 13 & 11 & 11 & 14 \\
\hline DYS393 & 13 & 13 & 12 & 13 & 13 & 13 & 13 \\
\hline DYS437 & 14 & 14 & 14 & 15 & 14 & 14 & 16 \\
\hline DYS438 & 11 & 11 & 10 & 12 & 10 & 11 & 12 \\
\hline DYS439 & 10 & 10 & 11 & 11 & 12 & 10 & 13 \\
\hline DYS448 & 20 & - & 21 & 19 & 20 & 20 & 19 \\
\hline DYS456 & 16 & 16 & 15 & 16 & 15 & 17 & 15 \\
\hline DYS458 & 15 & 15 & 19.2 & 17 & 15 & 15 & 18 \\
\hline DYS635 & 23 & (23) & 21 & 23 & 22 & 23 & 23 \\
\hline GATA H4 & 13 & 13 & 11 & 11 & 11 & 12 & 11 \\
\hline \multicolumn{8}{|l|}{ Athey's Haplogroup ${ }^{\text {a }}$} \\
\hline Name & R1a & R1a & $\mathrm{J} 1$ & $\mathrm{R} 1 \mathrm{~b}$ & E1b1 & R1a & $\mathrm{R} 1 \mathrm{~b}$ \\
\hline Probability & $100 \%$ & $100 \%$ & $99.6 \%$ & $100 \%$ & $100 \%$ & $100 \%$ & $100 \%$ \\
\hline \multicolumn{8}{|l|}{ Frequencies in Y-HRD ${ }^{\mathrm{b}}$} \\
\hline Worldwide (in 136,433 ) & 0 & 0 & 0 & 0 & 0 & $2.4 \times 10^{-4}$ & 0 \\
\hline Eastern Europe (in 8,177 ) & & & & & & $2 \times 10^{-3}$ & \\
\hline Hungary (in 937) & & & & & & $2.1 \times 10^{-3}$ & \\
\hline \multicolumn{8}{|l|}{ Frequency in US-YSTR $^{c}$} \\
\hline Caucasian (in 7449) & 0 & 0 & 0 & 0 & 0 & $8.1 \times 10^{-4}$ & 0 \\
\hline
\end{tabular}

Consensus result in brackets means that the result occurred only once.

${ }^{\mathrm{a}}$ http://www.hprg.com/hapest5/ (accessed 09/03/2015); ${ }^{\mathrm{b}} \mathrm{http} / / / \mathrm{yhrd} . \operatorname{org}$ (Release 54; 06/06/2017); ${ }^{\mathrm{c}} \mathrm{https}: / / \mathrm{www}$. usystrdatabase.org (Release 4.2; 02/18/2017)
The autosomal STR results of II/52 showed the closest relationship to Béla III (Fig. 2). He could not, however, be the son or father of Béla III because of five excluding markers (Table 4). The simplex autosomal STR results of D2S441 and DS1358 markers confirmed the exclusion of paternity (online resource 9). The STR of Queen Anna did not support him as a son. The autosomal STR results of the other examined skeletons - in accordance with the Y results - indicated no "parent-child" relationship with the King and each other (online resource 8).

\section{Kinship analysis}

The autosomal STR results contradicted the paternity between King Béla III and II/52. The mitochondrial sequence results excluded siblingship, too. Apart from that, we also tested the hypothesis for siblingship versus nonrelationship based on the autosomal STR results using "Familias 3". The LR (likelihood ratio) for the alternative hypothesis was found to be 7.67 , which was inconclusive.
Testing the hypothesis for a grandfather-grandson (or unclenephew) relationship versus non-relationship resulted in an LR of 5.44, which corresponds to a probability of $84.46 \%$ (assuming a prior probability of 50\%). This result is indecisive for the hypothesis.

We performed pairwise analyses with all the other investigated persons using "Familias 3" and found no evidence for parent-child or sibling relationships.

\section{Database search}

There were no exact matches for the 17 Y-STR markers of Béla III (or II/52), I/3G, I/4H, II/53 or II/55 in the YHRD (http://yhrd.org. Release 54; 06/06/2017) and US Y-STR databases (https://www.usystrdatabase.org. Release 4.2; 02/18/ 2017). Only the haplotype of person II/54 occurred with $2.4 \times$ $10^{-4}$ frequency $(32 / 136,433)$ worldwide and with a frequency as high as $2 \times 10^{-3}$ in Eastern Europe (16/8,177), according to the YHRD (Table 3). The closest haplotype to that of King Béla was found as "1-Step-Neighbour" in the YHRD. This 


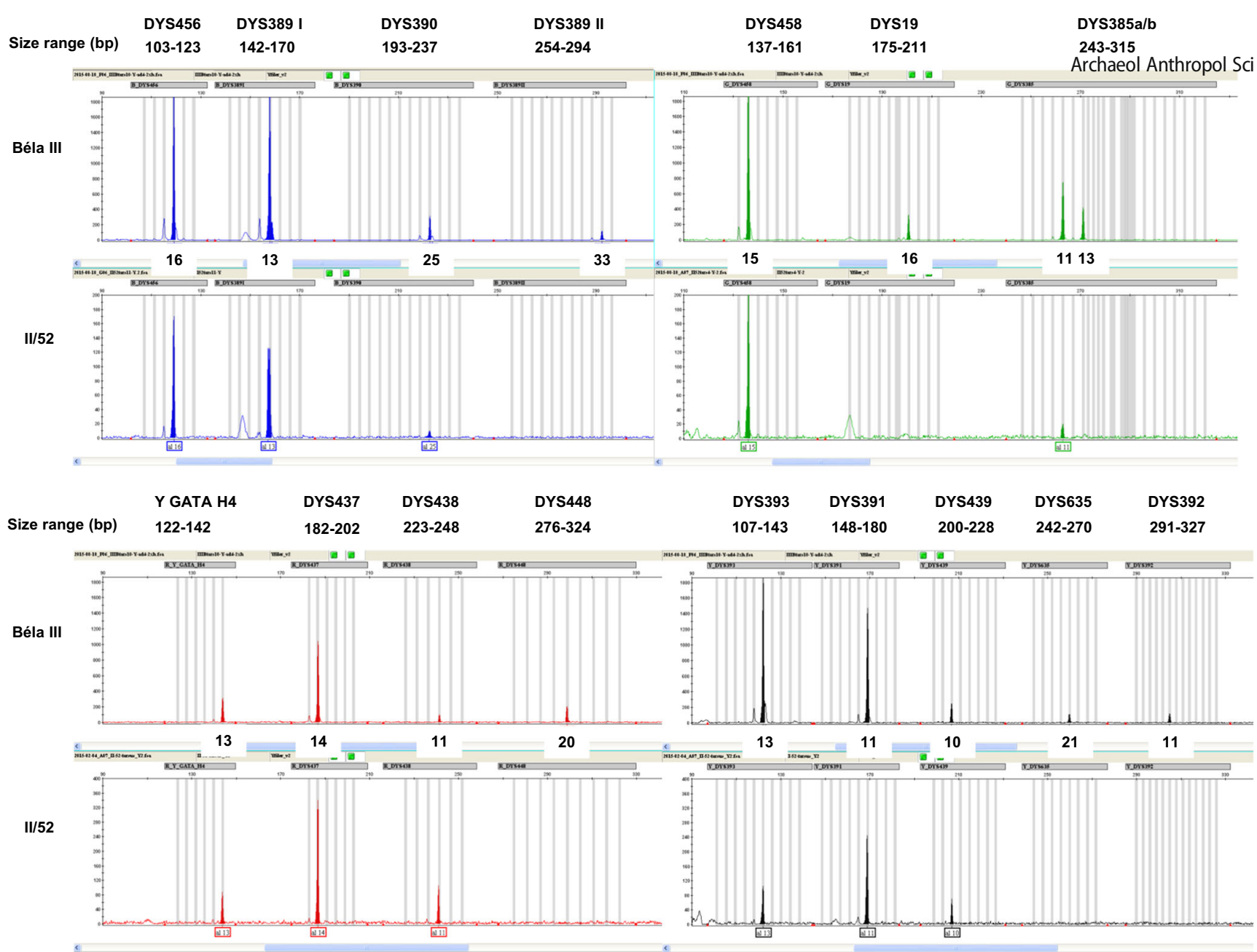

Fig. 1 Y-STR results generated with the AmpFISTR Yfiler kit (Applied Biosystems) for Béla III and person II/52

had 32 repeats compared to the King's 33 in marker DYS389II. This haplotype was discovered in the population living in Northern Serbia (Zgonjanin et al. 2017).

\section{Mitochondrial DNA analysis}

The first mitochondrial DNA sequencing results showed signs of contamination in the cases of Béla III and II/52. The new DNA extracts prepared with an additional $\mathrm{NaOCl}$ treatment showed clear sequences (online resource 10).

Polymorphisms of the mitochondrial control region in the samples of Béla III, Anna of Antioch and II/52 are listed in Table 5, and the detailed sequencing data are attached in online resource 10. The mitochondrial data proved that person II/52 was not related maternally to the King or Queen. Accordingly, he could not be their son or the brother of Béla III. The software programs EMPOP (http://empop.online. EMPOP 3; 07/27/2015) and Haplogrep2 (https://haplogrep.uibk.ac.at/, accessed 03/13/ 2016) estimated the following mitochondrial haplogroups: $\mathrm{H} 1 \mathrm{~b}$ for Béla III, H (H1j8 or H1bz) for Anna of Antioch and T (T2b2b1) for person II/52 (Table 5).

\section{Authenticity}

\section{DNA degradation}

DNA degradation of the ancient samples can be seen from the fragment size distribution of the multiplex STR PCR products. The inverse relationship between the PCR efficiency and the product size is demonstrated in Fig. 3. In this case, the maximal amplifiable fragment size was approximately $390 \mathrm{bp}$ in the tarsal sample of King Béla and approximately $320 \mathrm{bp}$ for the tarsal sample of II/52.

\section{Contamination}

During the sampling and laboratory procedures, we took the previously described precautions to prevent contamination of the ancient samples. Nevertheless, a number of people had come into direct contact with the skeletons since their discovery in the nineteenth century. We applied concentrated $\mathrm{NaOCl}$ 
Table 4 Autosomal STR genotypes of the royal skeletal remains

\begin{tabular}{|c|c|c|c|c|c|c|c|c|c|c|}
\hline & Béla III & & & Anna of & ntioch & & II/52 & & & Exclusion of paternity \\
\hline STR loci & B & G & Cons. & B & G & Cons. $^{a}$ & B & $\mathbf{G}$ & Cons. & \\
\hline Amelogenin & $\mathrm{X} / \mathrm{Y}$ & $\mathrm{X} / \mathrm{Y}$ & $\mathrm{X} / \mathrm{Y}$ & $\mathrm{X} / \mathrm{X}$ & $\mathrm{X} /$ & $\mathrm{X} / \mathrm{X}$ & $\mathrm{X} / \mathrm{Y}$ & $\mathrm{X} / \mathrm{Y}$ & $\mathrm{X} / \mathrm{Y}$ & \\
\hline D1S1656 & $13 / 17.3$ & $13 / 17.3$ & $13 / 17.3$ & $12 /-$ & $-/-$ & $12 /-$ & $12 / 17.3$ & $(12) /(17.3)$ & $12 / 17.3$ & \\
\hline D2S441 & $11 / 11.3$ & $11 / 11.3$ & $11 / 11.3$ & $10 /(14)$ & $(14) /-$ & $10 /(14)$ & $10 / 10$ & $(9) /(10)$ & $10 / 10$ & $\mathrm{X}$ \\
\hline D2S1338 & $17 / 17$ & $17 /-$ & $17 / 17$ & $20 / 27$ & $-/-$ & $20 / 27$ & $20 / 25$ & $(25) /-$ & $20 / 25$ & $\mathrm{X}$ \\
\hline D3S1358 & $15 / 17$ & $15 / 17$ & $15 / 17$ & $-/-$ & $16 /-$ & $16 /-$ & $14 / 14$ & $14 / 14$ & $14 / 14$ & $\mathrm{X}$ \\
\hline D5S818 & N/A & $10 / 12$ & $10 / 12$ & N/A & $14 /-$ & $14 /-$ & N/A & $10 / 12$ & $10 / 12$ & \\
\hline D7S820 & $10 / 11$ & $10 / 11$ & $10 / 11$ & $8 / 10$ & $-/-$ & $8 / 10$ & $8 / 9$ & $(8) / 9$ & $8 / 9$ & $\mathrm{X}$ \\
\hline D8S1179 & (13) & $13 / 14$ & $13 / 14$ & $-/-$ & $-/-$ & $-/-$ & $-/-$ & $12 / 14$ & $12 / 14$ & \\
\hline D9S1120 & N/A & $15 / 16$ & $15 / 16$ & N/A & $-/-$ & $-/-$ & N/A & $15 / 16$ & $15 / 16$ & \\
\hline D10S1248 & $13 / 13$ & $13 / 13$ & $13 / 13$ & $(14) / 15$ & $(14) /-$ & $(14) / 15$ & $13 / 13$ & $13 / 13$ & $13 / 13$ & \\
\hline D12S391 & $18 / 19$ & $18 / 19$ & $18 / 19$ & (18) & $(18) /(23)$ & 18/(23) & $17 /(18)$ & $(17) /(18)$ & $17 / 18$ & \\
\hline D13S317 & $9 / 13$ & $9 / 13$ & $9 / 13$ & $10 / 11$ & $11 /-$ & $10 / 11$ & $8 / 13$ & $8 / 13$ & $8 / 13$ & \\
\hline D16S539 & $11 / 12$ & $11 / 12$ & $11 / 12$ & $10 /(11)$ & $10 / 11$ & $10 / 11$ & $10 / 11$ & $10 / 11$ & $10 / 11$ & \\
\hline D18S51 & $13 / 16$ & $13 / 16$ & $13 / 16$ & $16 / 18$ & $18 /-$ & $16 / 18$ & $13 / 17$ & $13 / 17$ & $13 / 17$ & \\
\hline D19S433 & $15 / 16.2$ & $15 / 16.2$ & $15 / 16.2$ & $(15) /-$ & $-/-$ & $-/-$ & $13 / 13$ & $13 /-$ & $13 / 13$ & $X$ \\
\hline D21S11 & $31 / 32.2$ & $31 / 32.2$ & $31 / 32.2$ & $(29) / 30$ & $33 /-$ & $30 / 33$ & $30 / 32.2$ & $30 / 32.2$ & $30 / 32.2$ & \\
\hline D22S1045 & $15 / 16$ & $15 / 16$ & $15 / 16$ & 11/(17)- & $11 /-$ & $11 /-$ & $15 / 17$ & $(15) /(17)$ & $15 / 17$ & \\
\hline CSF1PO & $11 / 12$ & N/A & $11 / 12$ & $12 / 12$ & $\mathrm{~N} / \mathrm{A}$ & $12 / 12$ & $9 / 11$ & N/A & $9 / 11$ & \\
\hline FGA & $21 / 21$ & $21 / 21$ & $21 / 21$ & $21 / 23$ & $-/-$ & $21 / 23$ & $21 / 25$ & $21 / 25$ & $21 / 25$ & \\
\hline SE33 & N/A & $20 / 27.2$ & $20 / 27.2$ & N/A & $-/-$ & $-/-$ & $-/-$ & $-/-$ & $-/-$ & \\
\hline ТH01 & $7 / 9$ & $7 / 9$ & $7 / 9$ & 7/9.3 & 7/9.3 & $7 / 9.3$ & 9/9.3 & 9/9.3 & 9/9.3 & \\
\hline vWA & $17 / 17$ & $17 / 17$ & $17 / 17$ & $-/-$ & $-/-$ & $-/-$ & $16 / 17$ & $-/-$ & $16 / 17$ & \\
\hline
\end{tabular}

Consensus result in brackets means that the result occurred only once.

B consensus results from Budapest; G consensus results from Göttingen; Cons. Consensus; ${ }^{\text {a }}$ the consensus profile resulted from the pooled data of both laboratories; N/A not applicable

treatment in Göttingen and $0.5 \% \mathrm{NaOCl}$ and $\mathrm{UV}$ treatment in Budapest to eliminate DNA contamination. A decalcification procedure was performed in Budapest to access the deeper layers of bone tissue and to further reduce exogenous contamination. Despite these procedures, the specimens of II/52 femur and II/53 sternum remained significantly contaminated. Following an additional $\mathrm{NaOCl}$ treatment of the femur powder of II/52, some of the mitochondrial PCRs ran efficiently. The sequences of the amplified fragments were identical with those of the tarsal samples, thereby proving that the bone fragments belonged to the same individual.

The mitochondrial DNA from the tarsals of King Béla III and person II/52 showed few signs of contamination. That contamination was successfully eliminated with an additional $\mathrm{NaOCl}$ treatment of the bone powder.

Neither the negative extraction controls nor the no-template controls resulted in DNA amplification confirming that the laboratory reagents and disposables were not contaminated by the laboratory staff.

The results were compared with those originating from staff members and no matching sequences were found.

\section{Independent replication}

Several independent DNA extracts were used in both laboratories to establish and confirm the results.

\section{Discussion}

We investigated the remains of ten persons originating from the Székesfehérvár Royal Basilica and later placed into Matthias Church. Successful autosomal and Y-chromosomal STR typing was performed on the ancient samples. We also successfully performed sequence analysis on the control region of the mitochondrial DNA of three skeletons.

There were three R1a and two R1b statistically predicted $\mathrm{Y}$ haplogroups among the male skeletons (Table 3). These are the most frequent and second most frequent haplogroups (25.6 and $18.1 \%$ respectively) in the present Hungarian population (Völgyi et al. 2009). King Béla III was inferred to belong to haplogroup R1a. The R1a Y haplogroup relates paternally to more than $10 \%$ of men in a wide geographic area from South 


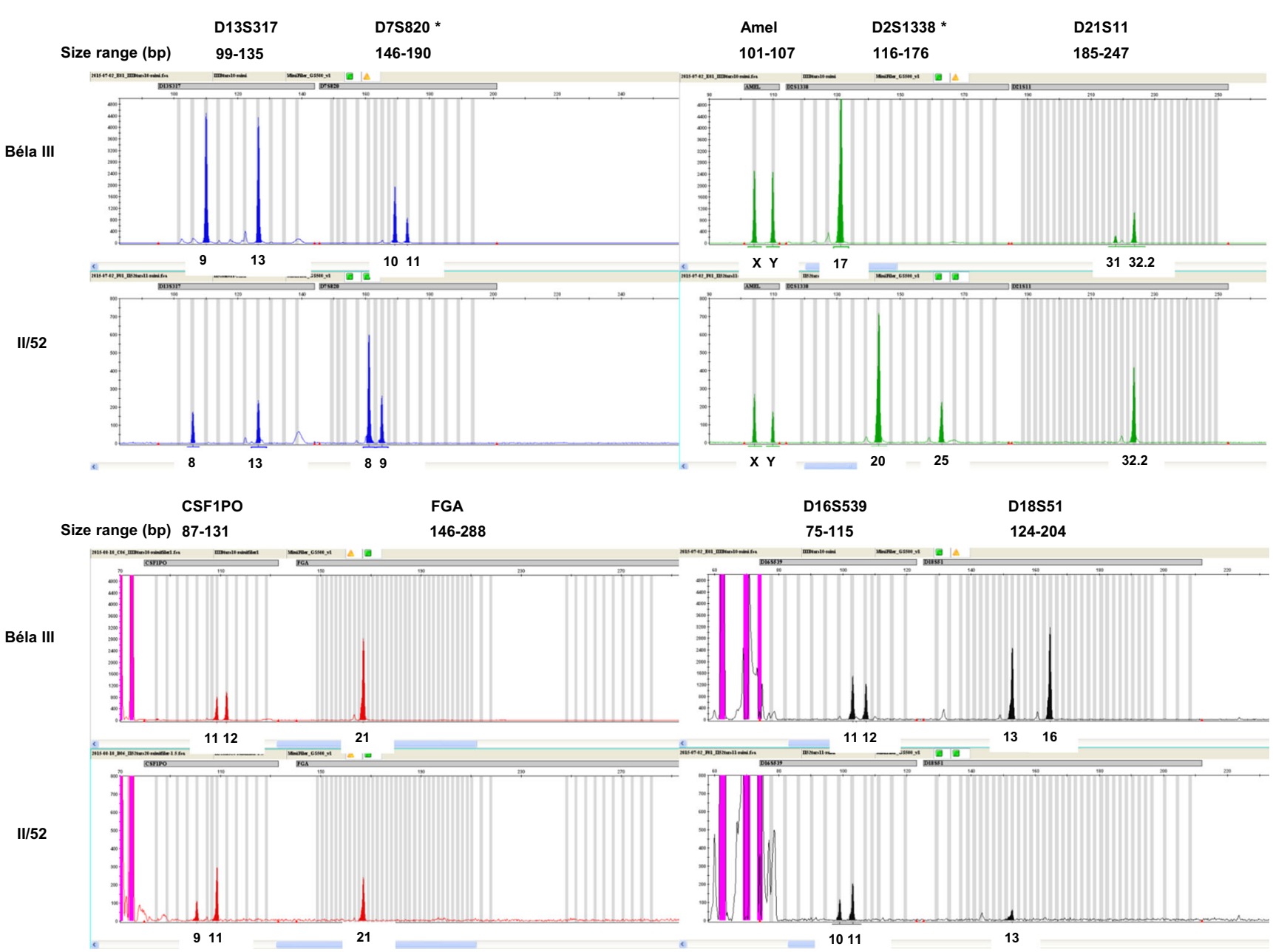

Fig. 2 Autosomal STR profiles of Béla III and person II/52 generated with AmpFlSTR MiniFiler (Applied Biosystems). *Markers D7S820 and D2S1338 revealed no shared alleles in the two persons, contradicting the paternity results. Each of the other six markers represented one shared allele

Asia to Central Eastern Europe and South Siberia (Underhill et al. 2010). It is the most frequent haplogroup in various populations speaking Slavic, Indo-Iranian, Dravidian, Turkic and Finno-Ugric languages (Underhill et al. 2010).
Table 5 The sequence variants found in the mitochondrial hypervariable regions of the examined persons

\begin{tabular}{llll}
\hline & Béla III & Anna of Antioch & II/52 \\
\hline Polymorphisms $^{\text {a }}$ & & & \\
HVR-I & $16183 \mathrm{C}$ & $16240 \mathrm{G}$ & $16126 \mathrm{C}$ \\
& $16189 \mathrm{C}$ & $16519 \mathrm{C}$ & $16192 \mathrm{~T}$ \\
& $16356 \mathrm{C}$ & & $16294 \mathrm{~T}$ \\
& $16519 \mathrm{C}$ & & $16519 \mathrm{C}$ \\
HVR-II & $263 \mathrm{G}$ & $263 \mathrm{G}$ & $73 \mathrm{G}$ \\
& $315.1 \mathrm{C}$ & $315.1 \mathrm{C}$ & $263 \mathrm{G}$ \\
HVR-III & & $315.1 \mathrm{C}$ \\
Haplogroup predictions & & & $517 \mathrm{G}$ \\
Haplogrep $^{\mathrm{b}}$ (Quality) & $\mathrm{H} 1 \mathrm{~b}(100 \%)$ & $\mathrm{H} 1 \mathrm{j} 8 / \mathrm{H} 1 \mathrm{bz}(100 \%)$ & $\mathrm{T}(81.07 \%)$ \\
EMPOP $^{\mathrm{c}}$ & $\mathrm{H} 1 \mathrm{~b}$ & $\mathrm{H}$ & $\mathrm{T} 2 \mathrm{~b} 2 \mathrm{~b} 1$ \\
\hline
\end{tabular}

HVR hypervariable region; ${ }^{a}$ Polymorphisms are given in reference to the revised Cambridge Reference Sequence, and the sequenced ranges were: 16009-16569 and 1-594; ${ }^{\mathrm{b}} \mathrm{https} / / /$ haplogrep.uibk.ac.at/ (accessed 03/13/2016); ${ }^{\mathrm{c} h t t p: / / e m p o p . o n l i n e ~(E M P O P ~ 3 ; ~ 07 / 27 / 2015) ~}$ 
Fig. 3 The inverse relationship between the STR fragment size and peak height. The DNA samples were amplified using the Investigator ESSplex Plus kit (Qiagen)

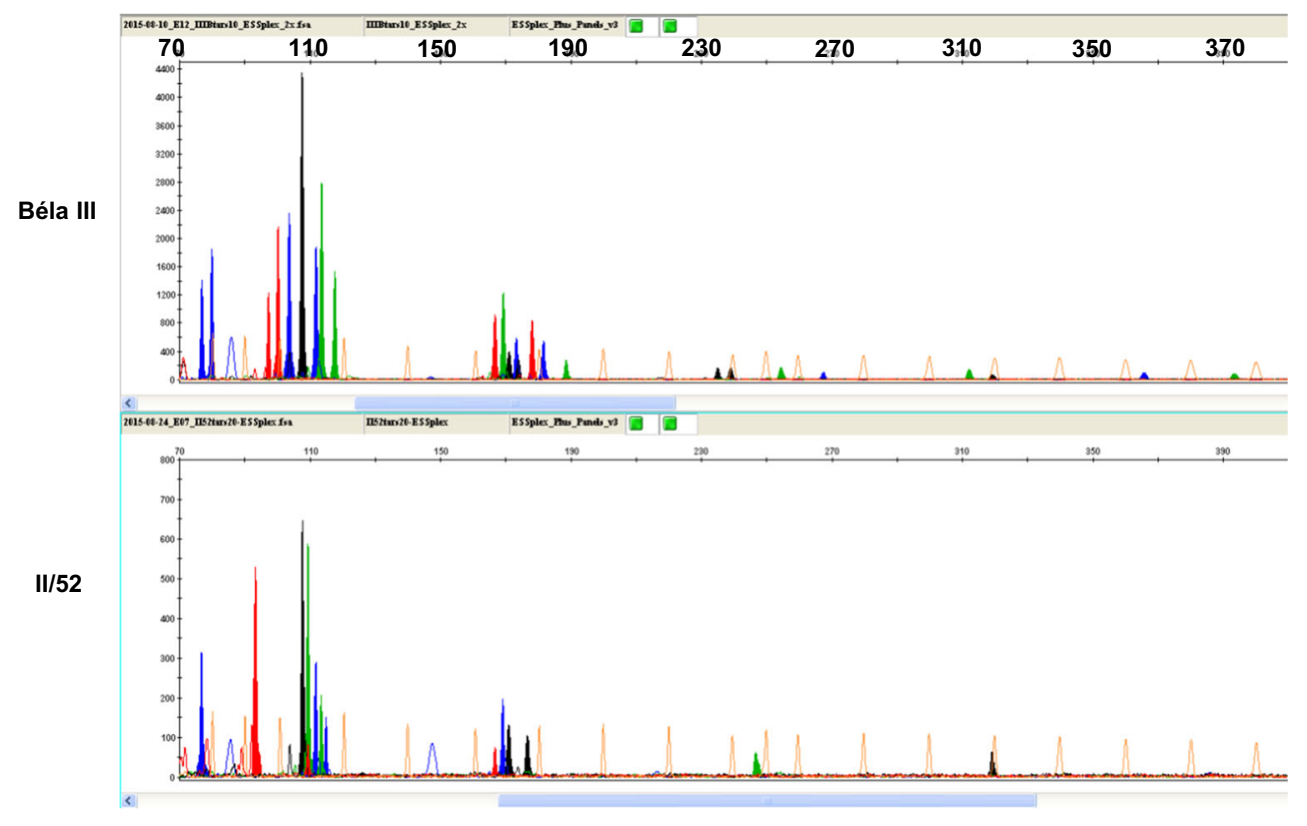

Only the skeleton denoted II/52 was found to be related to Béla III in the male lineage. Éry et al. (Éry 2008) doubted the authenticity of this skeleton for several reasons. They estimated the person's age at death as approximately 20-26 years old instead of the initial estimation of more than 30 years old (Érdy 1853). The number and types of missing bones were different from those on the original drawing (Éry 2008; Érdy 1853). The colour of the bones was much lighter than could be expected if they had been lying covered by mud for a long time. Nevertheless, it is reasonable to assume that the remains of the person paternally related to Béla III are the same as those originally found near the King's grave. Furthermore, during DNA extraction, the Budapest laboratory experienced a dark brown discolouration of the buffer (online resource 6), which was consistent with the presumed original colour of the skeleton. The grave depth was approximately $45 \mathrm{~cm}$ deeper than that of the royal couple. We suppose that groundwater might have flooded the grave for an extended period. Therefore, humic acids, which are soluble in alkaline conditions, could have been deeply absorbed by the bones. Former investigators probably washed the surface of the bones, leading to a lighter surface, but the decalcification buffer $(0.5 \mathrm{M}$ EDTA, pH 8.0) dissolved the deeply soaked dark brown humic acids.

Five out of 20 autosomal markers contradicted the paternity between Béla III and II/52. Four of them appeared homozygous in one of the two persons; nevertheless, several replicates, different PCR setups and simplex reactions for loci D2S441 and D3S1358 suggested the unlikeliness of allele drop-out events (online resource 9). The mitochondrial sequence results excluded siblingship, too. Therefore, we think a "grandfather-grandson" or an "uncle-nephew" relationship is more likely, although the LR value of 5.44 is quite low and not conclusive. However, this estimation is based on the allele frequencies of today's Hungarian population, since contemporary data are not known.

The inferred mitochondrial haplogroups were H1b for Béla III, H (H1j8 or H1bz) for Anna of Antioch and T2b2b1 for person II/52 (Table 5). The mitochondrial haplogroup H occurs with a frequency of $46 \%$ in Europe as a whole (Richards et al. 2000). H1b is found throughout the area of haplogroup H, but more frequently in Eastern Europe and North Central Europe (7 and $5 \%$ of $\mathrm{H}$, respectively) (Loogväli et al. 2004). It is in line with the fact that Béla the Third's mother was Euphrosyne of Kiev, a daughter of a noblewoman from Novgorod. Haplogroup $\mathrm{T} 2 \mathrm{~b}$ is frequent throughout Europe, mostly in Western Europe with a frequency of $4.16 \%$ (Pala et al. 2012). These facts bring us no closer to the identification of person II/52. His exact kinship relation to King Béla remains unknown.

The other five males were not found to be related to the King nor to each other in the male lineage (Table 3). These results support that in addition to royal family members, other dignitaries could be buried in the interior of the church. The typing results of the autosomal STRs revealed no direct relationship between any of the other studied persons.

No exact match with the King's STR haplotype was found in the current databases (Willuweit and Roewer 2015; Fatolitis and Ballantyne 2008). The closest haplotype to that of King Béla III was found in the YHRD and showed a one-repeat difference in marker DYS389II. The person with this haplotype is living in the population of present-day Northern Serbia (Zgonjanin et al. 2017). This geographical area belonged to Hungary before World War I, in the period of c.862-1920. Ethnic Hungarians have 
been continuously populating this area. The locality suggests that this person may be paternally related to the Árpád Dynasty. Nevertheless, sequencing data of the King's $\mathrm{Y}$ chromosome will be needed to get closer to the history of the Árpáds' haplotype.

In this study, the authors genuinely retrieved King Béla III's Y chromosome STR profile despite past human contamination of the bones. In the same church containing nine other analysed skeletons, they identified the same Y-STR profile in another male skeleton. This male skeleton is the only skeleton which shows an autosomal relationship to the King's autosomal profile. However, the two skeletons do not reveal an identical autosomal STR profile, thus excluding the possibility of contamination by one and the same researcher. The Y-STR profile of King Béla III can serve as a reference profile for the identification of further remains and disputed living descendants of the Árpád Dynasty. Currently available data are not sufficient to identify precisely the remains of the King's patrilineal relative found in the Royal Basilica of Székesfehérvár. Additional family members must be found and analysed to elucidate his kinship relations.

Acknowledgements The authors express their gratitude to Péter Erdő Cardinal, Archbishop of Esztergom-Budapest, for the permission to exhume the human remains, and to the Hungarian Government for the financial support. The authors would like to thank to Zoltán Doleschall for the technical help in the laboratory, to Piroska Biczó and Elek Benkő for the archaeological overview, to Balázs Mende and Piroska Rácz for the anthropological support, to Orsolya Csuka and László Patthy for the useful pieces of advice, to Rea Biacsi for the literature search and to Csaba Szabó and Tibor Vaszkó for the language polishing.

\section{Compliance with ethical standards}

Conflict of interest The authors declare that they have no conflict of interest.

Open Access This article is distributed under the terms of the Creative Commons Attribution 4.0 International License (http:// creativecommons.org/licenses/by/4.0/), which permits unrestricted use, distribution, and reproduction in any medium, provided you give appropriate credit to the original author(s) and the source, provide a link to the Creative Commons license, and indicate if changes were made.

\section{References}

Athey TW (2005) Haplogroup prediction from Y-STR values using an allele-frequency approach. J Genet Geneal 1:1-7

Eichmann C, Parson W (2008) 'Mitominis': multiplex PCR analysis of reduced size amplicons for compound sequence analysis of the entire mtDNA control region in highly degraded samples. Int J Legal Med 122(5):385-388. https://doi.org/10.1007/s00414-008-0227-5

Engel P (1987) Temetkezések a középkori székesfehérvári bazilikában [Burials in the medieval Basilica of Székesfehérvár]. Századok 121:613-637
Érdy J (1853) III. Béla király és nejének Székes-Fehérvárott talált síremlékei [The tombs of king Béla III and his spouse found in Székes-Fehérvár]. In: Kubinyi F, Vahot I (eds) Magyarország és Erdély képekben, vol. 1. Emich G, Pest, pp 42-48

Éry K (ed) (2008) A székesfehérvári királyi bazilika embertani leletei 1848-2002 [Human skeletal remains from the Royal Basilica of Székesfehérvár 1848-2002], Ecclesia Beatae Mariae Virginis Albaeregalis, vol, vol 1. Balassi Kiadó, Budapest

Fatolitis L, Ballantyne J (2008) The US Y STR Database. Profiles in DNA 11(1):13-14

Fehren-Schmitz L, Llamas B, Lindauer S, Tomasto-Cagigao E, Kuzminsky S, Rohland N, Santos FR, Kaulicke P, Valverde G, Richards SM, Nordenfelt S, Seidenberg V, Mallick S, Cooper A, Reich D, Haak W (2015) A re-appraisal of the early Andean human remains from Lauricocha in Peru. PLoS One 10(6):e0127141. https://doi.org/10.1371/journal.pone.0127141

Henszlmann I (1876) Magyarország ó-keresztyén, román és átmenet stylü mü-emlékeinek rovid ismertetése [Early Christian, romanesque and transitional style monuments in Hungary]. Magyar Királyi Egyetemi Könyvnyomda, Budapest, p 48

Hóman B (1940-1943) Geschichte des Ungarischen Mittelalters, vol 1-2. Walter de Gruyter, Berlin

Hummel S (2003) Authenticity of results. In: Hummel S ancient DNA typing methods, strategies and applications. Springer Publishers, Berlin, Heidelberg, New York, pp 131-157

King TE, Fortes GG, Balaresque P, Thomas MG, Balding D, Maisano Delser P, Neumann R, Parson W, Knapp M, Walsh S, Tonasso L, Holt J, Kayser M, Appleby J, Forster P, Ekserdjian D, Hofreiter M, Schürer K (2014) Identification of the remains of King Richard III. Nat Commun 5:5631. https://doi.org/10.1038/ncomms6631

Kling D, Tillmar AO, Egeland T (2014) Familias - extensions and new functionality. Forensic Sci Int Genet 13:121-127. https://doi.org/10. 1016/j.fsigen.2014.07.004

Kloss-Brandstätter A, Pacher D, Schönherr S, Weissensteiner H, Binna R, Specht G, Kronenberg F (2011) HaploGrep: a fast and reliable algorithm for automatic classification of mitochondrial DNA haplogroups. Hum Mutat 32(1):25-32. https://doi.org/10.1002/ humu. 21382

Kovács E (1969) Die Grabinsignien König Bélas III. und Annas von Antiochien [Burial insignias of King Béla III and Anna of Antioch]. Acta Historiae Artium Academiae Scientiarum Hungaricae 15:3-24

Kralovánszky A (1989) Szent István király székesfehérvári sírja és kultuszhelye [The grave and place of worship of King Saint Stephen]. Folia Archaeologica 40:155-171

Krenke BE, Tereba A, Anderson SJ, Buel E, Culhane S, Finis CJ, Tomsey CS, Zachetti JM, Masibay A, Rabbach DR, Amiott EA, Sprecher CJ (2002) Validation of a 16-locus fluorescent multiplex system. J Forensic Sci 47(4):773-785

László G (1965) Szent László Győri ereklyetartó mellszobráról [The reliquary bust of Saint Ladislas in Győr]. Arrabona 7:157-209

László G (1996) The Magyars. Their life and civilisation, Corvina, Budapest

Loogväli EL, Roostalu U, Malyarchuk BA, Derenko MV, Kivisild T et al (2004) Disuniting uniformity: a pied cladistic canvas of mtDNA haplogroup H in Eurasia. Mol Biol Evol 21(11):2012-2021. https://doi.org/10.1093/molbev/msh209

Makk F (1989) The Árpáds and the Comneni. Political relations between Hungary and Byzantium in the 12th century. Akadémia Kiadó, Budapest

Molnár A, Zalán A, Horváth G, Pamjav H (2011) Allele distribution of the new European Standard Set (ESS) loci in the Hungarian population. Forensic Sci Int Genet 5(5):555-556. https://doi.org/10.1016/ j.fsigen.2010.06.002

Pala M, Olivieri A, Achilli A, Accetturo M, Metspalu E et al (2012) Mitochondrial DNA signals of late glacial recolonization of 
Europe from near eastern refugia. Am J Hum Genet 4 90(5):915924

Parson W, Dür A (2007) EMPOP - a forensic mtDNA database. Forensic Sci Int Genet 1(2):88-92. https://doi.org/10.1016/j.fsigen.2007.01.018

Pohl W (2003) A non-Roman empire in Central Europe. In: Goetz HW, Jarnut J, Pohl W (eds) Regna and Gentes. The relationship between late antique and early Medieval peoples and kingdoms in the transformation of the Roman world. Brill, Leiden-Boston, pp 571-595

Rak SÁ, Zalán A, Szabados G, Pamjav H (2010) Population genetic data on 15 STR loci in the Hungarian population. Forensic Sci Int Genet 5(5):543-544. https://doi.org/10.1016/j.fsigen.2009.12.001

Richards M, Macaulay V, Hickey E, Vega E, Sykes B, Guida V, Rengo C, Sellitto D, Cruciani F, Kivisild T, Villems R, Thomas M, Rychkov S, Rychkov O, Rychkov Y, Gölge M, Dimitrov D, Hill E, Bradley D, Romano V, Calì F, Vona G, Demaine A, Papiha S, Triantaphyllidis C, Stefanescu G, Hatina J, Belledi M, di Rienzo A, Novelletto A, Oppenheim A, Nørby S, al-Zaheri N, Santachiara-Benerecetti S, Scozzari R, Torroni A, Bandelt HJ (2000) Tracing European founder lineages in the near eastern mtDNA pool. Am J Hum Genet 67(5): 1251-1276. https://doi.org/10.1016/S0002-9297(07)62954-1

Seidenberg V, Schilz F, Pfister D, Georges L, Fehren-Schmitz L (2012) A new miniSTR heptaplex system for genetic fingerprinting of ancient DNA from archaeological human bone. J Archaeol Sci 39(10): 3224-3229. https://doi.org/10.1016/j.jas.2012.05.019

Szabados G (2011) Magyar államalapítások a IX-XI. században. Előtanulmány a korai magyar állam történelmének fordulópontjairól [Foundings of the Hungarian state in the 9th-11th centuries]. Szegedi Középkorász Mühely, Szeged

Szabados G (2016) Könyves Béla király? Egy székesfehérvári királysír azonosításáról [King Béla the Learned? On an identification of a royal grave in Székesfehérvár]. Alba Regia 44:193-204
Szentpétery I (ed) (1937-1938) Scriptores Rerum Hungaricarum, vol 1-2. Academia Litteraria Hungarica, Budapest

Szádeczky-Kardoss S (1990) The Avars. In: Sinor D (ed) The Cambridge history of early inner Asia. Cambridge University Press, Budapest, pp 206-228

Szőke BM (2014) The Carolingian Age in the Carpathian Basin. Hungarian National Museum, Budapest

Török A (1893) Jelentés III-ik Béla magyar király és neje testereklyéiről [Report on the corporeal relics of Hungarian king Béla III and his spouse]. Értekezések a Természettudományok Köréből 23(4):175355

Török A (1900) III. Béla és első hitvese földi maradványai [The remains of Béla III and his first spouse]. In: Forster G (ed) III. Béla magyar király emlékezete. Hornyánszky V, Budapest

Underhill PA, Myres NM, Rootsi S, Metspalu M, Zhivotovsky LA et al (2010) Separating the post-Glacial coancestry of European and Asian Y chromosomes within haplogroup R1a. Eur J Hum Genet 18(4):479-484

Urquhart A, Oldroyd NJ, Kimpton CP, Gill P (1995) Highly discriminating heptaplex short tandem repeat PCR system for forensic identification. BioTechniques 18(1):116-118, 120-121

Völgyi A, Zalán A, Szvetnik E, Pamjav H (2009) Hungarian population data for 11 Y-STR and 49 Y-SNP markers. Forensic Sci Int Genet 3(2):e27-e28. https://doi.org/10.1016/j.fsigen.2008.04.006

Willuweit S, Roewer L (2015) The new Y chromosome haplotype reference database. Forensic Sci Int Genet 15:43-48. Doi: https://doi.org/ 10.1016/j.fsigen.2014.11.024

Zgonjanin D, Alghafri R, Antov M, Stojiljković G, Petković S, Vuković R, Drašković D (2017) Genetic characterization of 27 Y-STR loci with the Yfiler Plus kit in the population of Serbia. Forensic Sci Int Genet pii S1872-4973(17):30155-30152. https://doi.org/10.1016/j. fsigen.2017.07.013 